$\operatorname{Nr} 8$

WARSZAWA-KRAKÓW 2006

ZBIGNIEW ZIOŁO

Akademia Pedagogiczna, Kraków

\title{
Zróżnicowanie światowej przestrzeni przemysłowej w świetle koncentracji siedzib zarządów wiodących korporacji
}

W procesie nasilających się procesów globalizacji podstawową rolę odgrywają wiodące korporacje, które poprzez różnorodne systemy sieciowych powiązań przestrzenno-produkcyjnych organizują światową przestrzeń gospodarczą zgodnie ze swoimi regułami rozwoju. Przejawia się to $\mathrm{w}$ określonych kierunkach i nasileniu powiązań w zakresie: zaopatrzenia surowcowego, dostaw kooperacyjnych, rynków zbytu, przepływów technologii, kapitału oraz decyzji. Działania te prowadzą do utrwalania i pogłębiania istniejących rynków oraz utrwalania lokalizacji działalności poszczególnych oddziałów, a także poszukiwania nowych miejsc lokalizacji i nowych rynków zaopatrzenia oraz zbytu gotowych produktów.

Szczególnie ważną rolę w tym zakresie odgrywają siedziby zarządów wiodących firm światowych, które pełnią funkcję centrów decyzyjnych. W zarządach, w oparciu o przyjęte założenia strategiczne wynikające $\mathrm{z}$ analizy dotychczasowego przebiegu procesu kształtowania się gospodarki i przewidywanych tendencji przemian w sytuacji światowej, a także w układach krajowych czy regionalnych, a nawet miejscowych, podejmowane są decyzje dotyczące: przepływu środków finansowych związanych z kierunkami prac badawczo-rozwojowych, nowych lokalizacji, rozbudowy istniejących mocy produkcyjnych, wielkości i asortymentu produkcji, stopnia jego unowocześniania, kierunków zaopatrzenia i powiązań kooperacyjnych, rynków zbytu gotowych produktów, działalności marketingowej i in. W sieciowych powiązaniach korporacji szczególnie ważną rolę odgrywa lokalizacja oddziałów czy zakładów produkcyjnych, filii itp., które rozproszone w światowej przestrzeni zarządzane są przez decydentów związanych z poszczególnymi zarządami zlokalizowanymi na terenie niekiedy odległych krajów, regionów, metropolii czy mniejszych miast. Wskazują na to badania empiryczne dotyczące powiązań sieciowych przemysłu (Stryjakiewicz 2001, Tkocz 2003, Wieloński 2003, Zioło 2003), lokalizacji zarządów wiodących firm światowych (Zioło 2001, Zioło, Piróg 2002, Gierańczyk, Stańczyk 2003, Sala 2003), powiązań w zakresie napływu bezpośrednich inwestycji zagranicznych (Domański 2002, Rachwał 2003, Stańczyk 2003, Namyślak 2004) czy kształtowania się wiodących firm światowych (Wajda 2003, Wajda, Zakrzewska 2003, Wajda, Zorićić-Wołek 2003, Huculak 2004).

W świetle przedstawionych założeń w niniejszych rozważaniach podjęta zostanie problematyka przestrzennej koncentracji siedzib zarządów 1007 największych światowych firm w przekroju 2004 r. Zmierzać będziemy do określenia stopnia koncentracji przestrzennej ich siedzib, zróżnicowania sektorowego oraz wielkości potencjału ekonomicznego, którym zarządzają.

W 2004 r. wiodące korporacje światowe charakteryzują się bardzo zróżnicowanym potencjałem ekonomicznym. Wskazuje na to wahająca się wartość rynkowa największych

\footnotetext{
* Wartość rynkowa jest ceną akcji z 31 maja 2004 r. pomnożoną przez liczbę wyemitowanych papierów wartościowych i przeliczoną na USD według kursu z ostatniego dnia maja. Wartość rynkowa może obejmować
} 
światowych firm, która waha się od 328,1 mld dol. USD do 2,8 mld dol. USD, czyli jak 1: 17 (tab. 1). Pierwszą pozycję w światowym rankingu zajmuje General Electric o wartości rynkowej 328,1 mld dol. USD, czyli 1,6\% wartości analizowanych firm, który reprezentuje sektor przemysłowy, drugą pozycję zajmuje Microsoft, korporacja reprezentująca sektor informatyki, następnie Exxon Mobil, reprezentujący sektor energii, Pfizer (sektor opieki zdrowotnej), Wal-Mart Stores (sektor artykułów konsumpcyjnych) oraz Citigroup (sektor finanse). Sześć największych korporacji światowych ma siedziby swoich zarządów na terenie USA, reprezentują różne sektory i łącznie obejmują 6,9\% wartości rynkowej analizowanych firm. Wśród 20 największych korporacji dominującą rolę odgrywają firmy mające swoją siedzibę na terenie USA, na terenie których ulokowano 15 zarządów, mniejszą rolę pod tym względem odgrywa Wielka Brytania, gdzie znajdują się tylko trzy zarządy i Japonia (jedna siedziba zarządu).

Poszczególne korporacje charakteryzują się poważnym zróżnicowaniem w zakresie innych cech. W świetle wartości sprzedaży* ${ }^{*}$ pierwszą pozycję zajmuje Wal-Mari Stores (258,7 mld dol. USD), a następnie BP (232,6 mld dol.) i Exxon Mobil, które reprezentują handel i energię. Dalsze miejsca zajmują Toyota Moto i General Electric reprezentujące sektor artykułów luksusowych (przemysł samochodowy) i sektor przemysłu. Pod względem wielkości zysku pierwszą pozycję zajmuje Exxon Mobil (21,0 mld dol. USD), Citigroup i General Electric, a znacznie mniejszymi wartościami cechowały się pozostałe korporacje. Natomiast pod względem aktywów zdecydowanie dominują i zajmują pierwsze pozycje instytucje finansowe Citigroup i HSBC Holdings. Z uwagi na brak kompletnych danych dotyczących wartości przedstawionych cech, $w$ dalszych rozważaniach posługujemy się wartością rynkową korporacji, która podana jest dla wszystkich 1007 największych światowych korporacji. Znacznie niższym potencjałem odznaczają się firmy zajmujące ostatnie pozycje w strukturze rangowej 1007 największych firm światowych, a ich wartość rynkowa waha się od 5,4 mld dol. USD do 2,8 mld. Reprezentuja je firmy mające swoje pojedyncze siedziby w Indiach, Japonii, Korei, Francji, USA, Hongkongu, Chinach, Australii i Wielkiej Brytanii. Największe korporacje o wartości rynkowej od 200 do 400 mld dol. USD reprezentowane są przez sześć firm, które stanowią $0,6 \%$ ogólnej liczby korporacji światowych i skupiają 7,9\% wartości rynkowej analizowanych korporacji (tab. 2). Następna grupa, korporacje od $100 \mathrm{mld}$ dol. do $200 \mathrm{mld}$, obejmuje 19 jednostek, tj. 1,9\% ich ogólnej liczebności, a skupia 13,1\% wartości rynkowej. Te 25 największych korporacji, które stanowią tylko 2,5\% ogólnej liczebności, obejmują łącznie $21,0 \%$ wartości rynkowej wiodących światowych firm. Najliczniej reprezentowane są korporacje najmniejsze o wartości rynkowej od 2 mld do 10 mld. Reprezentuje je blisko połowa, bo aż 464 firm, które stanowią 46,1\% ogólnej liczebności, a skupiają 16,0\% wartości rynkowej. Kolejną bardzo liczną grupę, bo 288, stanowią korporacje o wartości rynkowej od $10 \mathrm{mld}$ dol. do $20 \mathrm{mld}$ dol. Te dwie grupy wielkościowe firm łącznie stanowią 74,7\% jednostek, które obejmują $35,1 \%$ wartości rynkowej.

różnego rodzaju akcje. Cena i stopa dywidendy są wyliczane na podstawie wyemitowanych akcji (BusinessWeek, nr 13/14, 5 sierpnia-1 września 2004 r., s. 58).

** Wartość sprzedaży określa sprzedaż netto podana przez spółkę wyrażoną według kursów z 31 maja 2004 r. Przychody banków oraz instytucji finansowych są często nieuwzględniane, ponieważ są nieporównywalne z przychodami innych przedsiębiorstw (BusinessWeek, nr 13/14, 5 sierpnia - 1września 2004 r., s. 58). 


\begin{tabular}{|c|c|c|c|c|c|c|c|c|c|c|c|c|c|c|c|}
\hline 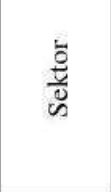 & 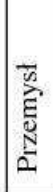 & 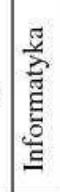 & 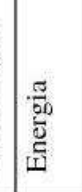 & 胥 & 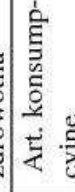 & 总 & 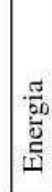 & 冕 & 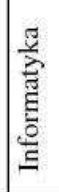 & 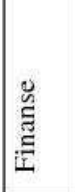 & 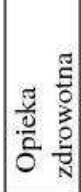 & 总 & 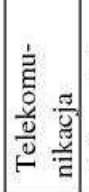 & 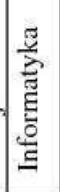 & 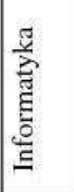 \\
\hline 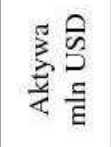 & $\begin{array}{l}\hat{m} \\
\hat{y} \\
\hat{f}\end{array}$ & $\begin{array}{l}\bar{n} \\
2 \\
2\end{array}$ & $\begin{array}{l}\infty \\
\vdots \\
\vdots \\
\pm \\
\pm\end{array}$ & \begin{tabular}{l}
\multirow{2}{N}{} \\
6 \\
$=$
\end{tabular} & 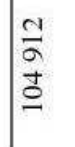 & 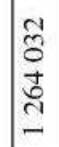 & $\begin{array}{l}\tilde{E} \\
\text { है }\end{array}$ & $\begin{array}{l}0 \\
0 \\
5 \\
0 \\
6 \\
6\end{array}$ & $\frac{9}{9}$ & $\begin{array}{l}7 \\
7 \\
0 \\
0 \\
2\end{array}$ & 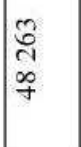 & $\begin{array}{l}3 \\
\infty \\
8\end{array}$ & 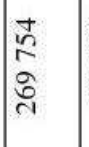 & $\frac{b}{m}$ & $\begin{array}{l}5 \\
\frac{5}{q} \\
0 \\
\underline{a}\end{array}$ \\
\hline 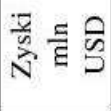 & $\begin{array}{l}\delta \\
\delta \\
-2\end{array}$ & $\hat{\alpha}$ & ¿ : & है & $\begin{array}{l}\overrightarrow{0} \\
\infty \\
\infty\end{array}$ & $\begin{array}{l}\approx \\
\infty \\
\cong\end{array}$ & ma & 范 & $\begin{array}{l}\text { E } \\
\text { in }\end{array}$ & $\cong \frac{0}{\infty}$ & $\frac{a}{n}$ & $=\frac{8}{8}$ & $\begin{array}{l}\text { J } \\
\text { m } \\
=\end{array}$ & $\begin{array}{l}\infty \\
\infty \\
\vdots \\
m\end{array}$ & $\begin{array}{l}\infty \\
\infty \\
n \\
r \\
r\end{array}$ \\
\hline 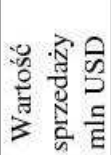 & 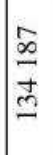 & $\frac{\infty}{\infty}$ & $\begin{array}{l}\infty \\
\infty \\
\approx \\
\tilde{z}\end{array}$ & $\frac{\infty}{\infty}$ & $\begin{array}{l}\bar{\infty} \\
\infty \\
\infty \\
\end{array}$ & . & $\begin{array}{l}\text { है } \\
\text { तै }\end{array}$ & $\frac{\tilde{m}}{\infty}$ & $\frac{\Xi}{\Xi}$ & . & 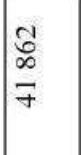 & . & $\begin{array}{l}\text { ते } \\
\text { के } \\
\text { की }\end{array}$ & $\begin{array}{l}\infty \\
\infty \\
\infty \\
\infty \\
\simeq\end{array}$ & $\begin{array}{l}\overrightarrow{2} \\
\vec{\infty}\end{array}$ \\
\hline 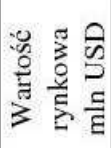 & $\begin{array}{l}\stackrel{0}{=} \\
\infty \\
\infty \\
\infty\end{array}$ & 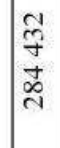 & $\begin{array}{l}m \\
0 \\
0 \\
2 \\
2\end{array}$ & $\begin{array}{l}\hat{8} \\
0 \\
\text { ¿ें }\end{array}$ & $\frac{\infty}{\infty}$ & $\begin{array}{l}\tilde{\gamma} \\
\tilde{q} \\
\hat{े}\end{array}$ & 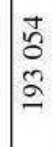 & $\frac{\infty}{a}$ & $\begin{array}{l}\overline{0} \\
0 \\
\pm \\
0\end{array}$ & $\begin{array}{l}1 \\
0 \\
0 \\
0 \\
0\end{array}$ & $\begin{array}{l}\tilde{1} \\
\tilde{n} \\
\tilde{3}\end{array}$ & $\begin{array}{l}0 \\
0 \\
0 \\
0\end{array}$ & 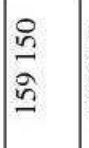 & $\begin{array}{l}\tilde{N} \\
\tilde{N} \\
\tilde{N}\end{array}$ & $\begin{array}{l}\bar{n} \\
\text { nn } \\
n \\
n\end{array}$ \\
\hline 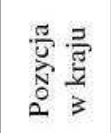 & - & 4 & $\mathrm{~m}$ & t & in & 6 & - & r & $\infty$ & $a$ & 인 & $\mathrm{ar}$ & $m$ & $=$ & $\simeq$ \\
\hline 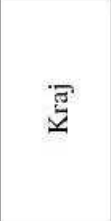 & 芯 & 芯 & 占 & 艿 & 岁 & 艿 & 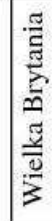 & $\underset{s}{5}$ & 艿 & 昏 & 艿 & 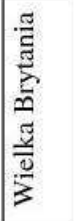 & 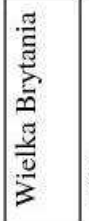 & 岁 & s. \\
\hline 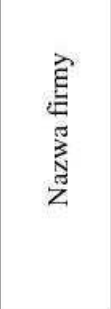 & 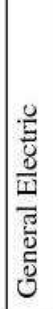 & 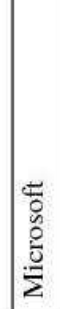 & 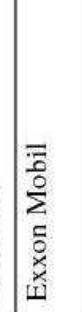 & 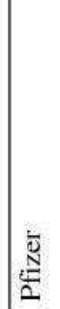 & 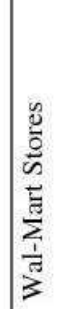 & 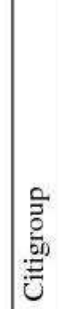 & $\frac{2}{x}$ & 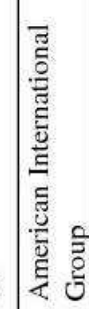 & $\frac{\infty}{\frac{\infty}{\underline{J}}}$ & 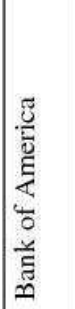 & 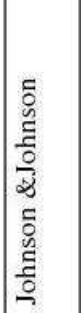 & 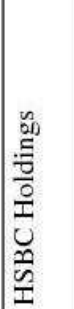 & 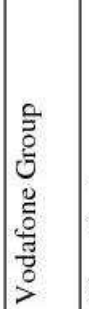 & 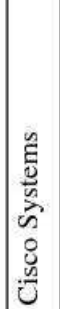 & 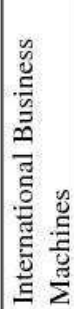 \\
\hline 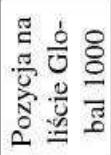 & - & 4 & $m$ & + & in & 6 & r & $\infty$ & a & $=$ & $\simeq$ & $\approx$ & \pm & $\cong$ & $\cong$ \\
\hline
\end{tabular}




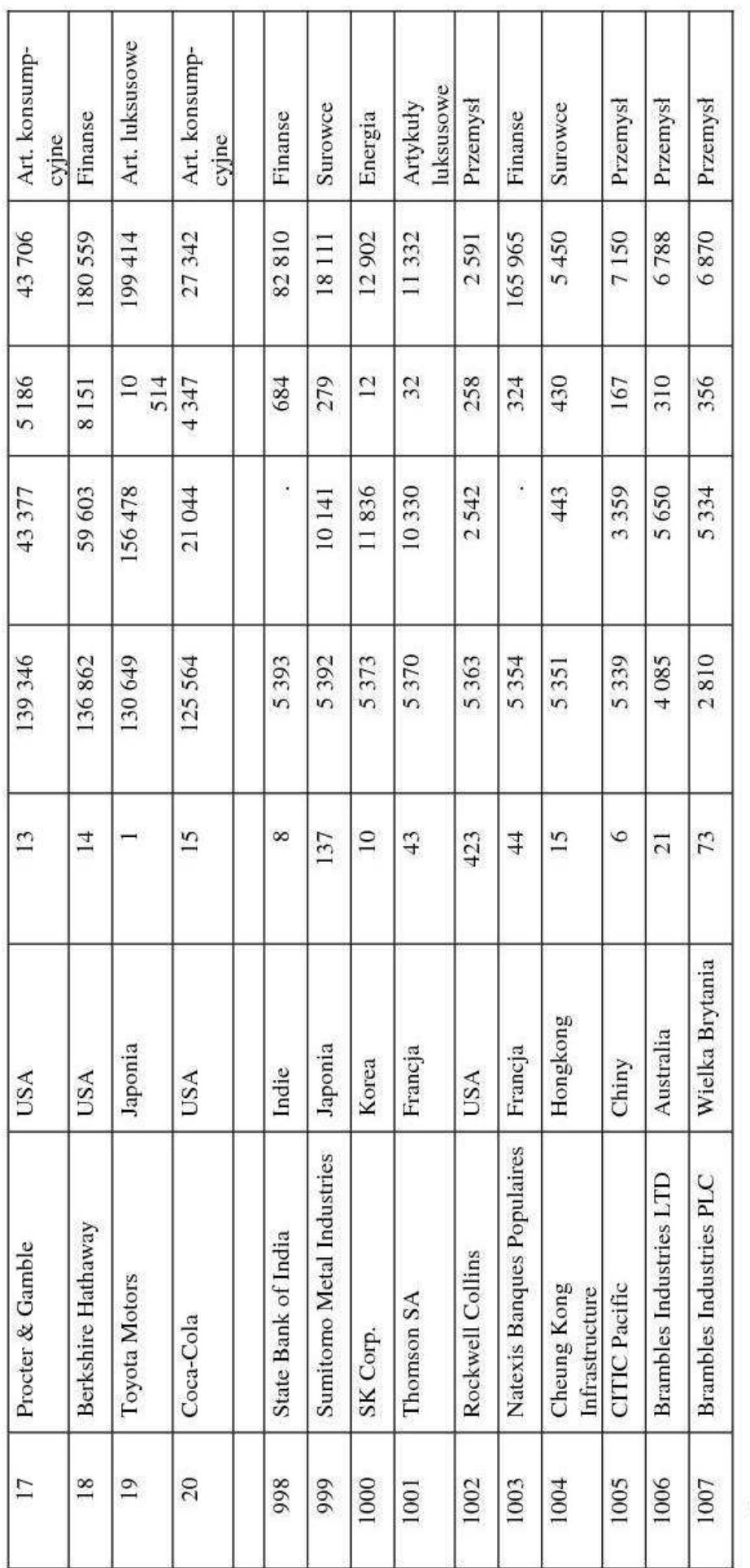


Tabela 2. Struktura wielkościowa światowych firm według wartości rynkowej w $2004 \mathrm{r}$.

\begin{tabular}{|c|c|c|c|c|}
\hline \multirow{2}{*}{$\begin{array}{c}\text { Przedziały wartości } \\
\text { rynkowej korporacji } \\
\text { w mld dol }\end{array}$} & Liczba & Wartość rynkowa & \multicolumn{2}{|c|}{ Struktura } \\
\cline { 4 - 5 } & korporacji & w mln USD & $\begin{array}{c}\text { Liczebności } \\
\text { korporacji }\end{array}$ & $\begin{array}{c}\text { Wartości } \\
\text { rynkowej }\end{array}$ \\
\hline $2-10$ & 464 & 3379261 & 46,1 & 16,0 \\
\hline $10-20$ & 288 & 4023745 & 28,6 & 19,1 \\
\hline $20-50$ & 171 & 5226644 & 17,0 & 24,8 \\
\hline $50-100$ & 59 & 4059092 & 5,9 & 19,3 \\
\hline $100-150$ & 10 & 1219960 & 1,0 & 5,8 \\
\hline $150-200$ & 9 & 1529082 & 0,9 & 7,3 \\
\hline $200-300$ & 5 & 1318330 & 0,5 & 6,3 \\
\hline $300-400$ & 1 & 328110 & 0,1 & 1,6 \\
\hline Ogółem & 1007 & 21084224 & 100,0 & 100,0 \\
\hline
\end{tabular}

Źródło: obliczenia własne na podstawie Global 1000, 2004 r.

Wysoki stopień zróżnicowania 1007 największych światowych korporacji określa wysoka wartość wskaźnika koncentracji potencjału ekonomicznego ${ }^{*}$, który wynosi 0,396, co podkreśla duże dysproporcje występujące między poszczególnymi firmami w zakresie wartości rynkowej. Analizowane firmy reprezentowane są przez różne sektory gospodarki (tab. 3). Najliczniej występują tu korporacje finansowe obejmujące 245 jednostek, a następnie korporacje reprezentujące produkcję artykułów luksusowych (141), przemysłowe (114) i informatyczne (104). Łącznie obejmują one 59,9\% ogólnej liczby korporacji i obejmują 56,2\% wartości rynkowej. Pod względem wartości rynkowej również dominują korporacje związane z finansami (24,3\% wartości rynkowej), a kolejne pozycje zajmują korporacje reprezentujące informatykę $(10,3)$, artykuły luksusowe i opiekę zdrowotną. Łącznie obejmują one 55,8\% korporacji, które skupiają 58,2\% wartości rynkowej. Mniejszym udziałem odznaczają się korporacje reprezentujące przemysł, energię i telekomunikację, a najmniejszym firmy usług komunalnych i surowcowe.

Poszczególne sektory obejmują korporacje, które odznaczają się dużym zróżnicowaniem w zakresie średniej wartości rynkowej. Podczas gdy przeciętna wartość analizowanych korporacji wynosi 20,9 mld dol., to średnia wartość korporacji poszczególnych sektorów waha się od 31,0 mld do 13,0 mld. Największą średnią wartością odznaczają się korporacje reprezentujące ochronę zdrowia, które w głównym stopniu reprezentują firmy związane $\mathrm{z}$ przemysłem farmaceutycznym i kosmetycznym (31,0 mld dol.), następnie firmy telekomu-

* Wskaźnik koncentracji potencjału ekonomicznego korporacji $\left(\mathrm{W}_{\mathrm{k}}\right)$ określa relacje między udziałem liczebności korporacji a udziałem ich wartości rynkowej, które określa wzór:

$$
\mathrm{W}_{\mathrm{k}}=\frac{\sum_{\mathrm{I}=1}^{\mathrm{h}}\left|\mathrm{k}_{\mathrm{i}}-\mathrm{p}_{\mathrm{i}}\right|}{200}
$$

gdzie: $\quad$ k - udział liczebności korporacji w i-tej grupie wielkościowej, p-udział wartości rynkowej korporacji w i-tej grupy wielkościowej.

Wartość wskaźnika zmienia się w przedziale (od 0 do 1), jeżeli zbliża się do zera, oznacza, że mamy do czynienia ze zbliżonym potencjałem ekonomicznym korporacji, czyli poszczególne korporacje niewiele różnią się pod względem wartości rynkowej, jeżeli zbliża się do jedności, mamy do czynienia z rosnącym zróżnicowaniem potencjału poszczególnych korporacji. 
nikacyjne (27,2 mld dol.). W miarę wyrównanymi średnimi wartościami (około 24 mld dol.) charakteryzują się korporacje reprezentujące sektor: energii, artykułów konsumpcyjnych, informatyki, a najniższymi (około 13 mld dol.), korporacje reprezentujące usługi komunalne i surowce.

Tabela 3. Wiodące firmy światowe według sektorów i wartości rynkowej (w mln USD)

\begin{tabular}{|c|l|c|c|c|c|c|}
\hline Lp. & \multicolumn{1}{|c|}{ Sektory } & $\begin{array}{c}\text { Liczba } \\
\text { firm }\end{array}$ & $\begin{array}{c}\text { Wartość rynkowa } \\
\text { w mln USD }\end{array}$ & $\begin{array}{c}\text { Struktura } \\
\text { firm }\end{array}$ & $\begin{array}{c}\text { Struktura } \\
\text { wartości } \\
\text { rynkowej }\end{array}$ & $\begin{array}{c}\text { Przeciętna } \\
\text { wartość ryn- } \\
\text { kowa firmy } \\
\text { w mn USD }\end{array}$ \\
\hline 1 & Finanse & 245 & 5105330 & 24,3 & 24,2 & 20838,1 \\
\hline 2 & Informatyka & 104 & 2518759 & 10,3 & 11,9 & 24218,8 \\
\hline 3 & $\begin{array}{l}\text { Artykuły } \\
\text { luksusowe }\end{array}$ & 141 & 2398215 & 14,0 & 11,4 & 17008,6 \\
\hline 4 & Opieka zdrowotna & 73 & 2265049 & 7,2 & 10,7 & 31028,1 \\
\hline 5 & $\begin{array}{l}\text { Artykuły } \\
\text { konsumpcyjne }\end{array}$ & 85 & 2074281 & 8,4 & 9,8 & 24403,3 \\
\hline 6 & Przemysł & 714 & 1838983 & 11,3 & 8,7 & 16131,4 \\
\hline 7 & Energia & 57 & 1551745 & 5,7 & 7,4 & 27223,6 \\
\hline 8 & $\begin{array}{l}\text { Telekomuni- } \\
\text { kacja }\end{array}$ & 57 & 754556 & 5,7 & 3,6 & 13237,8 \\
\hline 9 & $\begin{array}{l}\text { Usługi } \\
\text { komunalne }\end{array}$ & 57 & 744346 & 5,7 & 3,5 & 13058,7 \\
\hline 10 & Surowce & 1007 & 21084224 & 100,0 & 100,0 & 20937,7 \\
\hline & Ogółem & & & & \\
\hline
\end{tabular}

Źródło: obliczenia własne na podstawie Global 1000, 2004 r.

Oznacza to, iż pod względem liczebności i wartości rynkowej dominującą rolę odgrywają instytucje finansowe, które poprzez stymulowanie postępującym procesem koncentracji kapitału wywierają największy wpływ na pobudzanie rozwoju działalności gospodarczej. Drugą pozycję zajmują korporacje związane z informatyką, które w przestrzeni gospodarczej, także na terenie Polski, pojawiły się najpóźniej i obecnie w głównym stopniu umożliwiają wkraczanie gospodarki w informacyjną fazę rozwoju społecznego (Zioło 2004). Postępujący proces polaryzacji zasobów finansowych ludności oraz wykształcanie się coraz bogatszych grup społecznych wpłynął na przesunięcie się na drugą pozycję w rankingu korporacji związanych z artykułami luksusowymi. Wzrost zasobów finansowych ludności i rozszerzanie się grupy warstwy średniej oraz coraz wyższa świadomość dbania o własne zdrowie wpłynęły na postęp farmakologii, biotechnologii i metod leczenia, co przyczyniło się do znacznego rozwoju korporacji związanych z ochroną zdrowia, a rosnące potrzeby ludności wpływają na zwiększanie roli firm produkujących artykuły konsumpcyjne. Natomiast osłabienie roli przemysłu oraz surowców i usług komunalnych, jako bazy ekonomicznego rozwoju, w głównym stopniu wpłynęły na zmniejszenie znaczenia reprezentujących je korporacji w strukturze największych firm światowych. 
Tabela 4. Siedziby zarządów wiodących firm światowych w 2004 r.

\begin{tabular}{|c|c|c|c|c|c|c|c|c|}
\hline \multirow[b]{2}{*}{ Lp. } & \multirow[b]{2}{*}{ Kraj } & \multirow[b]{2}{*}{$\begin{array}{l}\text { Liczba } \\
\text { firm }\end{array}$} & \multirow{2}{*}{$\begin{array}{c}\text { Wartość } \\
\text { rynkowa firm } \\
\text { w mln USD }\end{array}$} & \multicolumn{2}{|c|}{ Struktura } & \multirow{2}{*}{$\begin{array}{c}\text { Przeciętna } \\
\text { wartość firmy } \\
\text { w mln USD }\end{array}$} & \multicolumn{2}{|c|}{ Struktura } \\
\hline & & & & $\begin{array}{l}\text { Liczby } \\
\text { firm }\end{array}$ & $\begin{array}{l}\text { Wartości } \\
\text { rynkowej }\end{array}$ & & Obszar & $\begin{array}{l}\text { Liczba } \\
\text { ludności }\end{array}$ \\
\hline 1 & USA & 423 & 10775398 & 42,0 & 51,1 & 25474 & 6,9 & 4,7 \\
\hline 2 & Japonia & 137 & 2039469 & 13,6 & 9,7 & 14887 & 0,2 & 2,1 \\
\hline 3 & $\begin{array}{l}\text { Wielka } \\
\text { Brytania }\end{array}$ & 73 & 1860726 & 7,2 & 8,8 & 25489 & 0,2 & 1,0 \\
\hline 4 & Francja & 44 & 990051 & 4,4 & 4,7 & 22501 & 0,4 & 1,0 \\
\hline 5 & Niemcy & 35 & 719772 & 3,5 & 3,4 & 20565 & 0,3 & 1,3 \\
\hline 6 & Szwajcaria & 16 & 603608 & 1,6 & 2,9 & 37726 & 0,0 & 0,1 \\
\hline 7 & Kanada & 37 & 483519 & 3,7 & 2,3 & 13068 & 7,4 & 0,5 \\
\hline 8 & Włochy & 23 & 452754 & 2,3 & 2,1 & 19685 & 0,2 & 0,9 \\
\hline 9 & Holandia & 15 & 379124 & 1,5 & 1,8 & 25275 & 0,0 & 0,3 \\
\hline 10 & Hiszpania & 17 & 364509 & 1,7 & 1,7 & 21442 & 0,4 & 0,6 \\
\hline 11 & Australia & 21 & 329312 & 2,1 & 1,6 & 15682 & 0,1 & 0,1 \\
\hline 12 & Szwecja & 15 & 205092 & 1,5 & 1,0 & 13673 & 0,3 & 0,1 \\
\hline 13 & Rosja & 9 & 196240 & 0,9 & 0,9 & 21804 & 12,6 & 2,3 \\
\hline 14 & Hongkong & 15 & 189593 & 1,5 & 0,9 & 12640 & 0,0 & 0,1 \\
\hline 15 & Tajwan & 18 & 178903 & 1,8 & 0,8 & 9939 & 0,0 & 0,4 \\
\hline 16 & Korea & 10 & 155807 & 1,0 & 0,7 & 15581 & 0,1 & 0,8 \\
\hline 17 & Belgia & 10 & 141661 & 1,0 & 0,7 & 14166 & 0,0 & 0,2 \\
\hline 18 & RPA & 11 & 108703 & 1,1 & 0,5 & 9882 & 0,9 & 0,7 \\
\hline 19 & Chiny & 6 & 104000 & 0,6 & 0,5 & 17333 & 7,1 & 20,8 \\
\hline 20 & Finlandia & 5 & 102315 & 0,5 & 0,5 & 20463 & 0,2 & 0,1 \\
\hline 21 & Meksyk & 6 & 79144 & 0,6 & 0,4 & 13191 & 1,4 & 1,7 \\
\hline 22 & Indie & 8 & 74613 & 0,8 & 0,4 & 9327 & 2,4 & 16,6 \\
\hline 23 & Brazylia & 5 & 71178 & 0,5 & 0,3 & 14236 & 6,3 & 2,8 \\
\hline 24 & Norwegia & 5 & 70801 & 0,5 & 0,3 & 14160 & 0,2 & 0,1 \\
\hline 25 & Dania & 4 & 67914 & 0,4 & 0,3 & 16979 & 0,0 & 0,1 \\
\hline 26 & Singapur & 5 & 64058 & 0,5 & 0,3 & 12812 & 0,0 & 0,1 \\
\hline 27 & Grecja & 8 & 50876 & 0,8 & 0,2 & 6360 & 0,1 & 0,2 \\
\hline 28 & Irlandia & 4 & 44405 & 0,4 & 0,2 & 11101 & 0,1 & 0,1 \\
\hline 29 & Malezja & 5 & 37392 & 0,5 & 0,2 & 7478 & 0,2 & 0,4 \\
\hline 30 & Portugalia & 3 & 28697 & 0,3 & 0,1 & 9566 & 0,1 & 0,2 \\
\hline 31 & Izrael & 2 & 25922 & 0,2 & 0,1 & 12961 & 0,0 & 0,1 \\
\hline 32 & Austria & 3 & 24610 & 0,3 & 0,1 & 8203 & 0,1 & 0,1 \\
\hline 33 & Tajlandia & 3 & 23729 & 0,3 & 0,1 & 7910 & 0,4 & 1,0 \\
\hline 34 & Polska & 2 & 10841 & 0,2 & 0,1 & 5421 & 0,2 & 0,6 \\
\hline 35 & Chile & 1 & 8995 & 0,1 & 0,0 & 8995 & 0,6 & 0,3 \\
\hline 36 & Indonezja & 1 & 8042 & 0,1 & 0,0 & 8042 & 1,4 & 3,5 \\
\hline 37 & $\begin{array}{l}\text { Nowa } \\
\text { Zelandia }\end{array}$ & 1 & 6606 & 0,1 & 0,0 & 6606 & 0,2 & 0,1 \\
\hline 38 & Wegry & 1 & 5845 & 0,1 & 0,0 & 5845 & 0,1 & 0,2 \\
\hline & Ogółem & 1007 & 21084224 & 100,0 & 100,0 & 20938 & 51,1 & 66,0 \\
\hline & $\begin{array}{l}\text { Reszta } \\
\text { świata }\end{array}$ & & & & & & 48,9 & 34,0 \\
\hline & Świat & & & & & & 100,0 & 100,0 \\
\hline
\end{tabular}

Źródło: obliczenia własne na podstawie Global 1000, 2004 r. 
Rozmieszczenie siedzib zarządów wiodących światowych firm wskazuje na duże zróżnicowanie przestrzeni światowej w zakresie jej atrakcyjności dla lokalizacji tych strategicznych ogniw zarządzania. Lokalizacje zarządów największych korporacji występują na terenie 38 krajów, które obejmują 51,1\% powierzchni ziemi, zamieszkanej przez 66,0\% ludności (tab. 4). Oznacza to, iż 48,9\% obszaru zamieszkanego przez 34,0\% ludności nie stwarza korzystnych warunków dla lokalizacji zarządów wiodących firm światowych, w których, jak wspomniano, podejmowane są decyzję dotyczące zwłaszcza przemieszczania zasobów kapitałowych oraz możliwości aktywizacji gospodarczej poszczególnych obszarów.

Najbardziej atrakcyjny pod tym względem jest obszar USA, gdzie zlokalizowano siedziby 423 zarządów wiodących firm światowych, które stanowią 42,0\% ich ogólnej liczebności, a zarządzają wartością rynkową 10,8 bil. dol., czyli 51,1\% wartości analizowanych korporacji. Drugą pozycję pod tym względem zajmuje Japonia, na terenie której skupia się 137 siedzib zarządów o wartości rynkowej obejmującej 9,7\% wartości ogólnej. Na terenie tych dwóch krajów, pełniących funkcję światowych biegunów wzrostu gospodarczego, skupia się łącznie 53,6\% analizowanych korporacji, które obejmują 60,8\% wartości rynkowej. $\mathrm{O}$ dużej koncentracji wartości rynkowej korporacji zarządzanych z terenu tych krajów świadczy fakt, iż, obejmują one tylko $7,1 \%$ powierzchni świata, na której skupia się $6,8 \%$ ludności. Kolejne pozycje zajmują: Wielka Brytania, Francja i Niemcy, rdzeniowe kraje UE, na terenie których zlokalizowano 152 zarządów wiodących firm światowych, dysponujących $16,9 \%$ wartości rynkowej związanych z nimi korporacji, a obejmują tylko $0,9 \%$ światowej powierzchni, zamieszkanej przez 3,3\% ludności. Dalsze pozycje zajmują Holandia, Hiszpania i Australia, na terenie których występuje 53 zarządów, obejmujących 5,1\% wartości rynkowej, a zamieszkane są przez 1,0\% ludności. W przestrzeni światowej obszar pierwszych 11 krajów jest najbardziej atrakcyjny dla lokalizacji zarządów wiodących światowych firm. Na ich terenie łącznie skupia się 841 zarządów firm dysponujących 90,1\% ich wartości rynkowej, podczas gdy na ich terenie mieszka tylko $12,6 \%$ ludności świata. Pozostałe 27 krajów występowania zarządów dominujących korporacji światowych odgrywa znacznie mniejszą rolę. Wśród nich występuje Polska reprezentowana przez Bank Pekao zajmujący w strukturze rangowej największych firm światowych 985 pozycję i Telekomunikacja Polska zajmująca 987 pozycję, łącznie obejmują one $0,1 \%$ wartości rynkowej.

Zarządy zlokalizowane na terenie poszczególnych krajów odznaczają się bardzo zróżnicowaną przeciętną wartością związanych z nimi korporacji, która waha się od 37,7 mld dol do 5,4 mld dol., czyli prawie jak 1:7. Najwyższą średnią wartością rynkową 37,7 mld dol. charakteryzują się firmy reprezentujące głównie instytucje finansowe (światowe banki) i ochronę zdrowia (korporacje farmaceutyczne), których zarządy znajdują się na terenie Szwajcarii. Kolejne pozycje zajmują firmy, których zarządy są zlokalizowane na terenie Wielkiej Brytanii (25,5 mld dol.), USA (25,5 mld dol.) i Holandii (25,3 mld dol.). Natomiast najniższymi średnimi wartościami charakteryzowały się korporacje, których zarządy zlokalizowane są na terenie Malezji (7,5 mld dol.), Nowej Zelandii (6,6 mld dol.), Grecji (6,4 mld. dol.), Węgier (5,8 mld. dol.) i Polski (5,4 mld dol.). Generalnie można przyjąć, że w przestrzeni światowej zaznacza się pewna prawidłowość a mianowicie, im na terenie poszczególnych krajów jest mniejsza liczba lokalizacji zarządów, tym mniejsza jest średnia wartość rynkowa korporacji, którymi zarządzają.

W przestrzeni światowej najbardziej atrakcyjne dla lokalizacji zarządów wiodących firm są więc trzy światowe bieguny wzrostu gospodarczego USA, Japonia i UE, na terenie których występuje 859 zarządów zarządzających korporacjami o łącznej wartości rynkowej 18,7 bil. dol. USD, tj. 88,9\% ogólnej wartości rynkowej, podczas gdy kraje te obejmują tylko 17,2\% powierzchni ziemi, na której mieszka 14,1\% ludności świata (tab. 5). Znacznie mniejszą rolę w tym zakresie odgrywa strefa okołopacyficzna, Australia i Nowa Zelandia 
oraz pozostałe kraje, na terenie których skupia się 148 zarządów korporacji o udziale wartości rynkowej związanych z nimi firm $11,1 \%$.

Tabela 5. Koncentracja przestrzenna siedzib zarządów wiodących firm światowych w 2004 r.

\begin{tabular}{|l|r|r|r|r|r|r|}
\hline \multirow{2}{*}{ Grupy państw } & \multirow{2}{*}{$\begin{array}{c}\text { Liczba } \\
\text { firm }\end{array}$} & \begin{tabular}{c} 
Wartość \\
rynkowa \\
firm w mln \\
\cline { 5 - 8 }
\end{tabular} & & \multicolumn{4}{|c|}{ Udział w procentach } \\
\hline USA, Kanada & 460 & 11258917 & 45,68 & 53,40 & 14,26 & \multicolumn{1}{c|}{$\begin{array}{c}\text { Wartości } \\
\text { rynkowej }\end{array}$} \\
\hline Japonia & 137 & 2039469 & 13,60 & 9,67 & 0,25 & 2,05 \\
\hline Unia Europejska & 262 & 5449192 & 26,02 & 25,84 & 2,69 & 6,85 \\
\hline Strefa okołopacyficzna & 63 & 761524 & 6,26 & 3,61 & 9,20 & 27,03 \\
\hline Australia, Nowa Zelandia & 22 & 335918 & 2,18 & 1,59 & 0,26 & 0,19 \\
\hline Pozostałe kraje & 63 & 1239204 & 6,26 & 5,88 & 24,48 & 24,70 \\
\hline Razem & 1007 & 21084224 & 100,00 & 100,00 & 51,15 & 66,01 \\
\hline Reszta świata & $\mathrm{x}$ & $\mathrm{x}$ & $\mathrm{x}$ & $\mathrm{x}$ & 48,85 & 33,99 \\
\hline Ogółem świat & $\mathrm{x}$ & $\mathrm{x}$ & $\mathrm{x}$ & $\mathrm{x}$ & 100,00 & 100,00 \\
\hline
\end{tabular}

Źródło: obliczenia własne na podstawie Global 1000, 2004 r.

Firmy mające swoją siedzibą na terenie poszczególnych krajów odznaczają się dużym zróżnicowaniem w strukturze rangowej (tab. 6). Czołowe miejsca zajmują korporacje mające swoje siedziby w USA - 29 zarządów z pierwszej pięćdziesiątki największych korporacji, czyli 58\% tej kategorii korporacji, 56 zarządów z pierwszej setki (czyli 56\%), 100 zarządów z pierwszej dwusetki (czyli 50\%) oraz $47 \%$ zarządów pierwszej trzech setki.

Firmy mające swoją siedzibę na terenie Japonii najczęściej występują w przedziale rangowym od 300 do 400 miejsca (22 zarządy), a w Wielkiej Brytanii w przedziale od 501 do 600 miejsca. Stosunkowo równomiernie we wszystkich przedziałach występują korporacje mające swoje siedziby na terenie Francji, Włoszech, Holandii i Hiszpanii.

Biorąc pod uwagę liczbę siedzib zarządów wiodących korporacji w poszczególnych krajach oraz ich miejsce w strukturze rangowej pod względem wartości rynkowej, zaznacza się wyraźna prawidłowość, a mianowicie - w miarę zmniejszania się liczebności siedzib zarządów korporacji na terenie poszczególnych krajów, zajmują one dalsze miejsca w strukturze rangowej oraz generalnie charakteryzują się coraz niższą przeciętną wartością rynkową związanych z nimi korporacji.

W strukturze sektorowej wiodących korporacji światowych dominują zarządy instytucji finansowych, które reprezentuje 245 zarządów, a następnie produkcję artykułów luksusowych (141) i przemysłowych (114) oraz informatykę (tab. 7). Znacznie mniejszą rolę odgrywają korporacje reprezentujące: surowce, telekomunikację i usługi komunalne. Podobnie w strukturze poszczególnych krajów najliczniej reprezentowane są korporacje finansowe. W strukturze zarządów występujących na terenie USA instytucje finansowe obejmują 94 zarządów, a firmy produkcji artykułów luksusowych (71) i informatyki (58) łącznie 52,7\% 


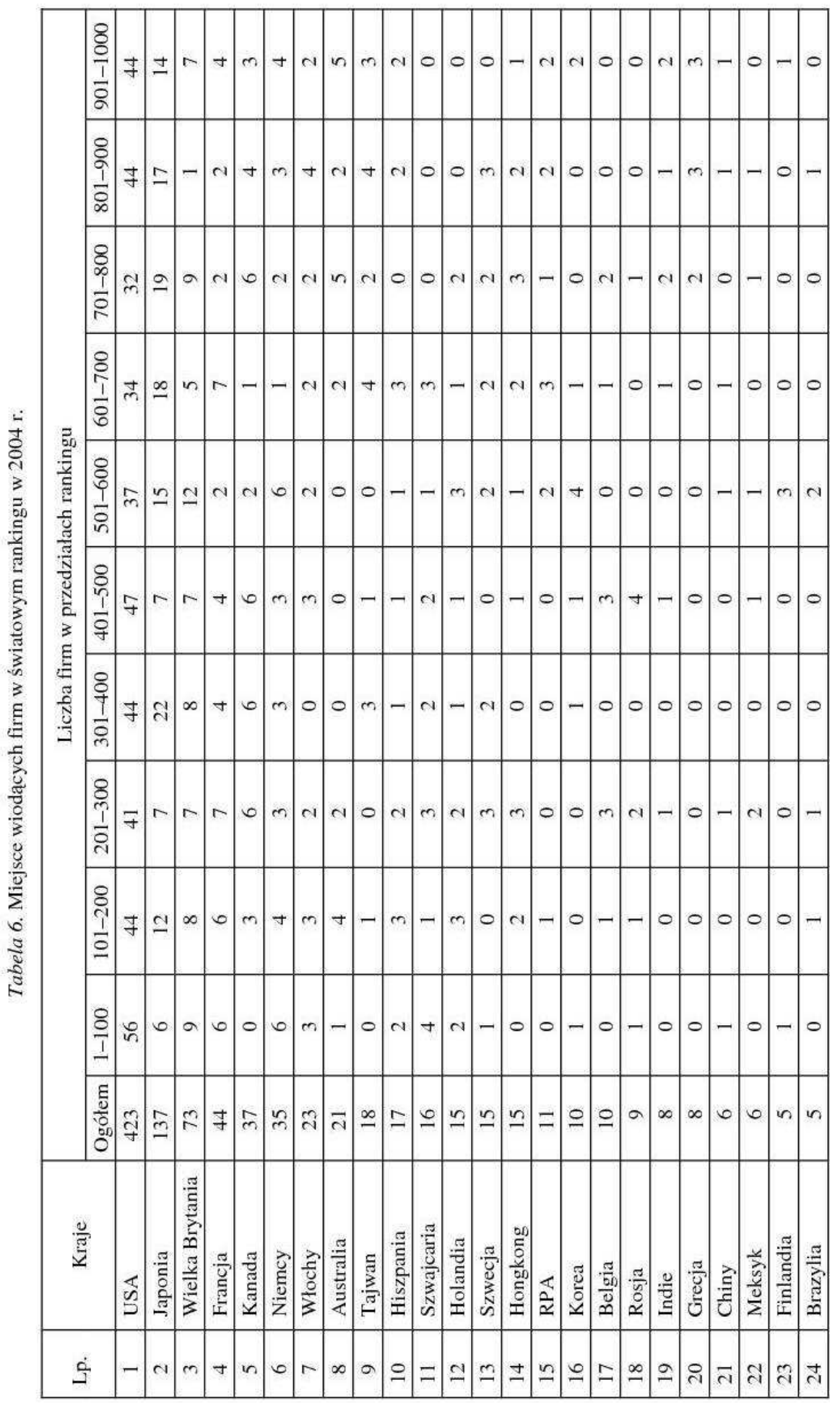




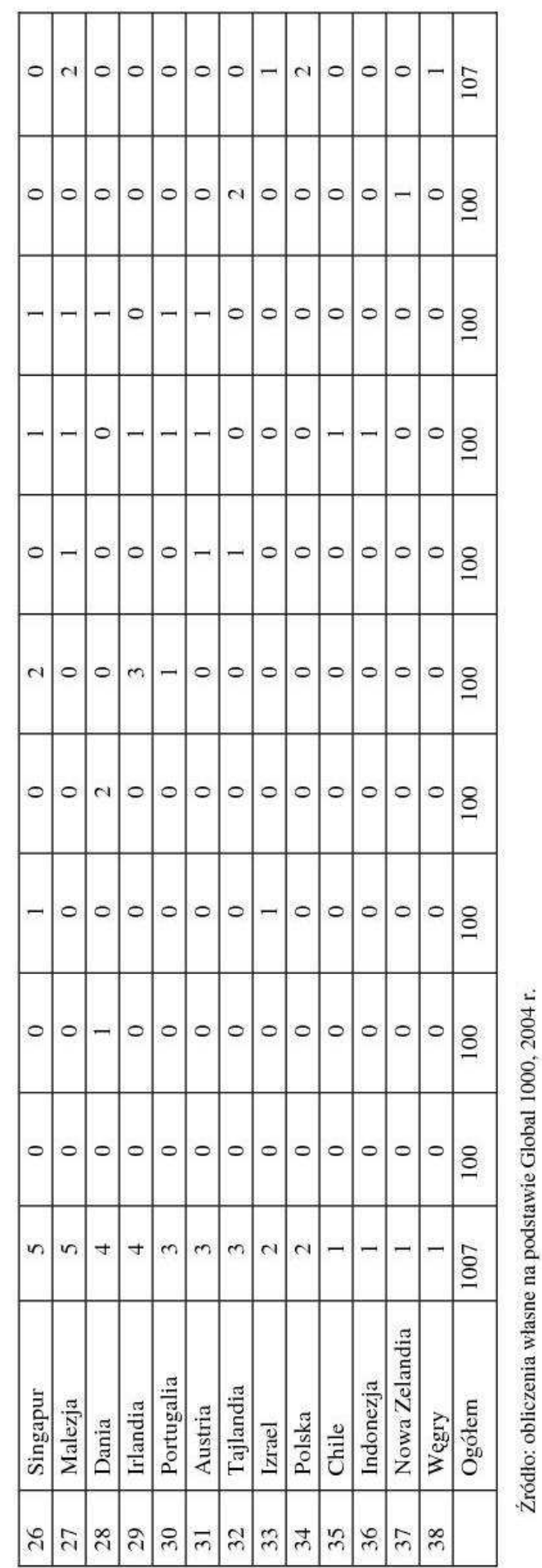




\begin{tabular}{|c|c|c|c|c|c|c|c|c|c|c|c|c|c|c|c|c|c|c|}
\hline & 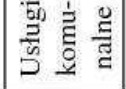 & $\hat{\imath}$ & $\infty$ & $n$ & $\mathrm{a}$ & $\alpha$ & & & $m$ & & t & & & - & $m$ & & - & - \\
\hline & 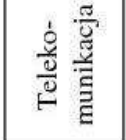 & $a$ & + & + & 4 & - & - & 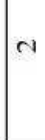 & $\mathrm{N}$ & - & A & - & N & - & & - & $\mathrm{N}$ & - \\
\hline & $\begin{array}{l}\text { 竞竞 } \\
\text { 音 }\end{array}$ & $\stackrel{\infty}{n}$ & ป & & $\alpha$ & $m$ & & N & & - & & & - & & & $\infty$ & - & \\
\hline & 宠 & ప & $\stackrel{\sim}{\sim}$ & $=$ & r & 6 & t & $\cong$ & $\simeq$ & $m$ & $\rightarrow$ & 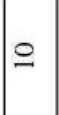 & in & - & $\infty$ & $n$ & - & in \\
\hline 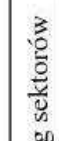 & 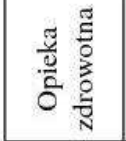 & F & $\infty$ & $\mathrm{m}$ & $\mathrm{m}$ & + & + & & & & & & & & & & & - \\
\hline 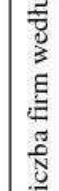 & 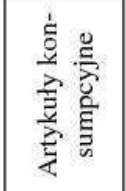 & $\stackrel{\sim}{\circ}$ & $\infty$ & $\cong$ & in & + & - & $\mathrm{N}$ & & 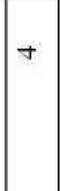 & - & $m$ & & & & & & - \\
\hline & 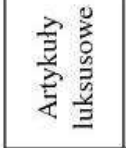 & $\pi$ & तి & $\cong$ & $\cong$ & 0 & $N$ & $\mathrm{O}$ & & $m$ & - & $\mathrm{A}$ & $\mathrm{N}$ & & & & $\mathrm{N}$ & \\
\hline & 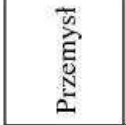 & 接 & $\stackrel{\sim}{\sim}$ & 6 & 0 & + & $A$ & $\mathrm{~N}$ & $m$ & - & $m$ & A & + & & $m$ & & - & \\
\hline & 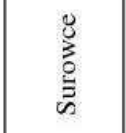 & $\cong$ & $\cong$ & $n$ & $m$ & & $a$ & t & $\alpha$ & - & & $a$ & - & - & - & t & - & - \\
\hline & $\begin{array}{l}\frac{5}{50} \\
\frac{50}{5} \\
\text { 童 }\end{array}$ & $\approx$ & - & m & - & in & & 인 & - & - & N & - & & in & & & - & \\
\hline & $\begin{array}{l}\frac{E}{5} \\
\frac{5}{0} \\
b^{\circ}\end{array}$ & $\hat{\mathcal{F}}$ & $\underline{m}$ & $\Re$ & 导 & $m$ & $\simeq$ & m & $\tilde{\AA}$ & $\cong$ & $=$ & $\bar{\wedge}$ & $\cong$ & $a$ & 2 & $\stackrel{\infty}{.}$ & 은 & 은 \\
\hline & $\overrightarrow{\underline{a}}$ & $\mid \begin{array}{l}\mathbb{5} \\
3\end{array}$ & 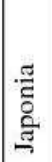 & 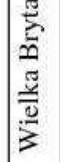 & 施 & $\begin{array}{l}\overrightarrow{\breve{E}} \\
\frac{\mathrm{U}}{Z}\end{array}$ & 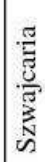 & 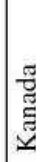 & $\begin{array}{l}\frac{3}{3} \\
\frac{0}{0} \\
\frac{0}{3}\end{array}$ & 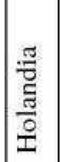 & 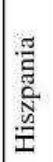 & 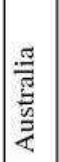 & $\begin{array}{l}\frac{\pi}{3} \\
\frac{0}{N} \\
n\end{array}$ & 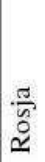 & 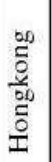 & 竞 & بَّ & $\frac{\pi}{\frac{\pi}{0}}$ \\
\hline & $\dot{s}$ & - & $a$ & m & + & in & 0 & r & $\infty$ & $a$ & 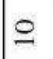 & $=$ & $\simeq$ & 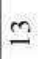 & \pm & $\simeq$ & 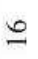 & - \\
\hline
\end{tabular}




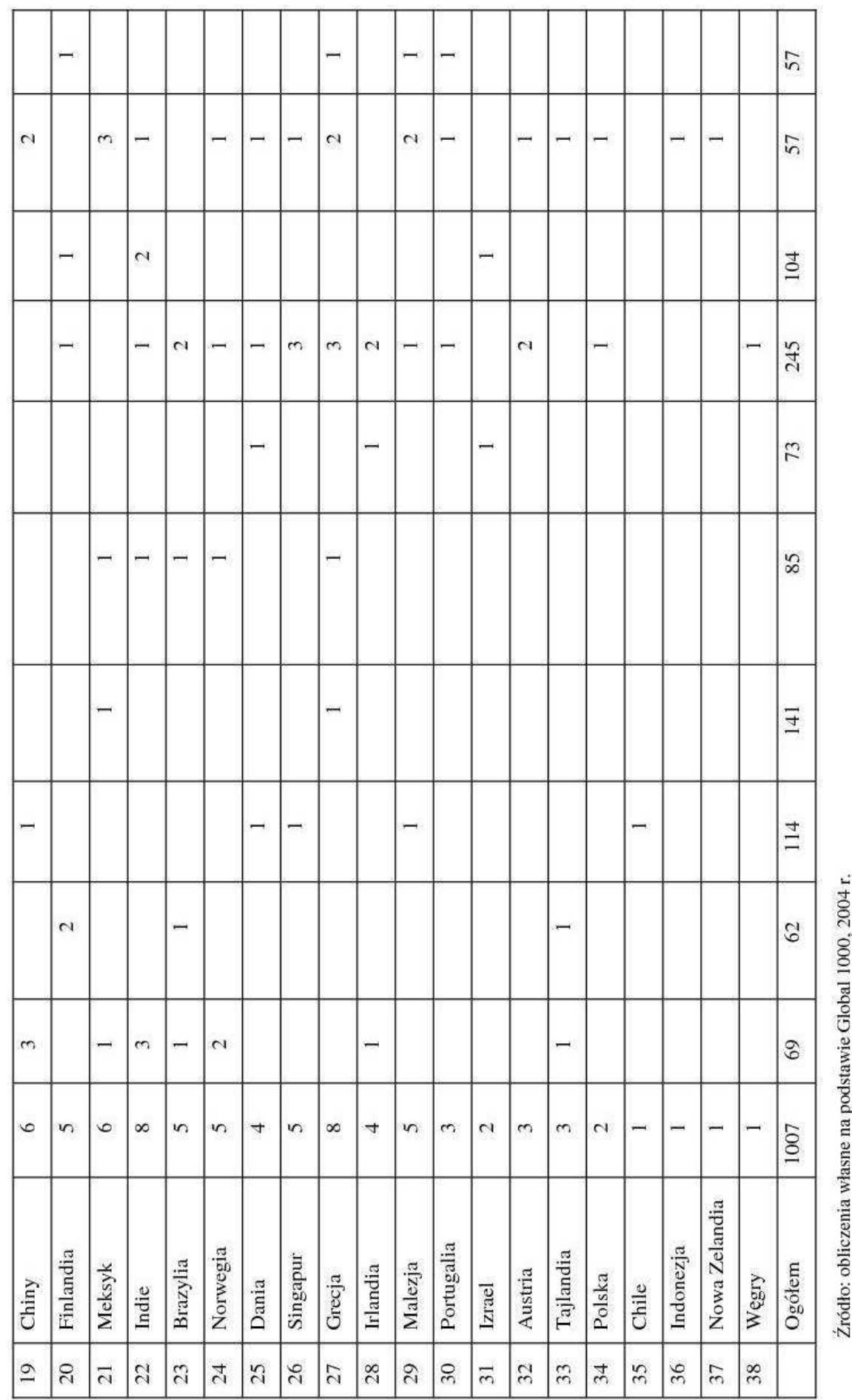


ogólnej liczby zarządów. W Japonii najliczniej reprezentowane są zarządy firm związane z korporacjami przemysłowymi (28 zarządów), finansowymi (26) i informatyką (24). W Wielkiej Brytanii zbliżoną liczbę mają instytucje finansowe (17), firmy produkujące artykuły luksusowe i artykuły konsumpcyjne (po 15). Natomiast we Francji dominują zarządy reprezentujące artykuły luksusowe (13) i instytucje finansowe (7). W Niemczech dominuja instytucje finansowe i produkujące artykuły luksusowe (po 6), a w Szwajcarii instytucje finansowe i ochrony zdrowia (po 4). W Kanadzie podobnie jak w Chinach po instytucjach finansowych na drugiej pozycji znajdują się firmy związane z energia.

Znaczący udział zarządów związanych z instytucjami finansowymi podkreśla ich znaczenie jako źródeł zasilania kapitałowego dla rozwoju pozostałych sektorów gospodarki. Natomiast udziały pozostałych sektorów wynikają z poziomu rozwoju gospodarczego, stąd w krajach najbardziej rozwiniętych drugą pozycję zajmują korporacje związane z produkcja artykułów luksusowych (Wielka Brytania, Francja, Niemcy). W krajach o podobnej kulturze dominującą rolę odgrywa sektor informatyki (Japonia, Tajwan) i sektor przemysłu (Japonia). Natomiast w strukturze sektorowej krajów charakteryzujących się słabszym poziomem rozwoju na drugiej pozycji znajdują się tradycyjny sektor energii (Kanada, Chiny) i surowcowy (RPA).

Zbliżona struktura sektorowa zaznacza się w zakresie wartości rynkowej największych firm światowych. (tab. 8). W większości krajów dominującą rolę odgrywają instytucje finansowe oraz sektory wymagające dużego nakładu środków: opieki zdrowotnej, energii, surowców i informatyki.

Przedstawiona analiza wskazuje na bardzo duże zróżnicowanie światowej przestrzeni gospodarczej w zakresie rozmieszczenia siedzib zarządów wiodących firm, co jest wyrazem nasilających się procesów polaryzacji, w wyniku których nadal będą rosły dysproporcje w tym zakresie. Dla lokalizacji zarządów największych światowych firm najbardziej korzystne warunki nadal będą występować na terenie trzech światowych biegunów wzrostu gospodarczego (USA, Japonii i Unii Europejskiej). W strukturze sektorowej utrwalać będą swoją pozycję najliczniej reprezentowane instytucje finansowe (które są głównym źródłem zasilania kapitałowego rozwoju gospodarczego), a następnie firmy związane z produkcją artykułów luksusowych (kierowaną do bogatej części społeczeństwa światowego), firmy przemysłowe (oferujące produkty bardziej powszechne) oraz informatyczne (przyśpieszające wdrażania informacyjnej fazy rozwoju).

Natomiast pod względem wartości rynkowe nadal utrzymują swoja pierwszą pozycję instytucje finansowe, na drugą pozycję przesunęły się firmy informatyczne, a następnie firmy produkujące artykuły luksusowe i związane z ochroną zdrowia. Wydaje się, iż sektorom tym w najbliższej przyszłość należy przypisać główną siłę motoryczną w zakresie wzrostu gospodarczego, która pociąga za sobą rozwój pozostałych sektorów. Wymienione sektory związane są z społeczeństwami bogatymi (finanse, artykuły luksusowe) oraz tworzą nową bazę ekonomicznego rozwoju umożliwiająca budowanie społeczeństwa opartego na wiedzy (informatyka, ochrona zdrowia - przemysł farmaceutyczny i biotechnologia).

Wydaje się, iż w świetle przeprowadzonych rozważań można zaproponować pewne sugestie odnoszące się do kształtowania krajowej strategii i przyjmowania nowych założeń dla przewidywanych kierunków rozwoju gospodarczego. Działania z tym związane powinny przejawiać się w trzech kierunkach, po pierwsze, dbanie o rozwój produkcji dostosowanej do chłonności naszego rynku, a ściślej do zasobów finansowych stosunkowo ubogiego społeczeństwa, któremu należy zabezpieczyć możliwie godne warunki egzystencji; po drugie, zmierzać do systematycznego zwiększania strumieni finansowych płynących do gospo- 


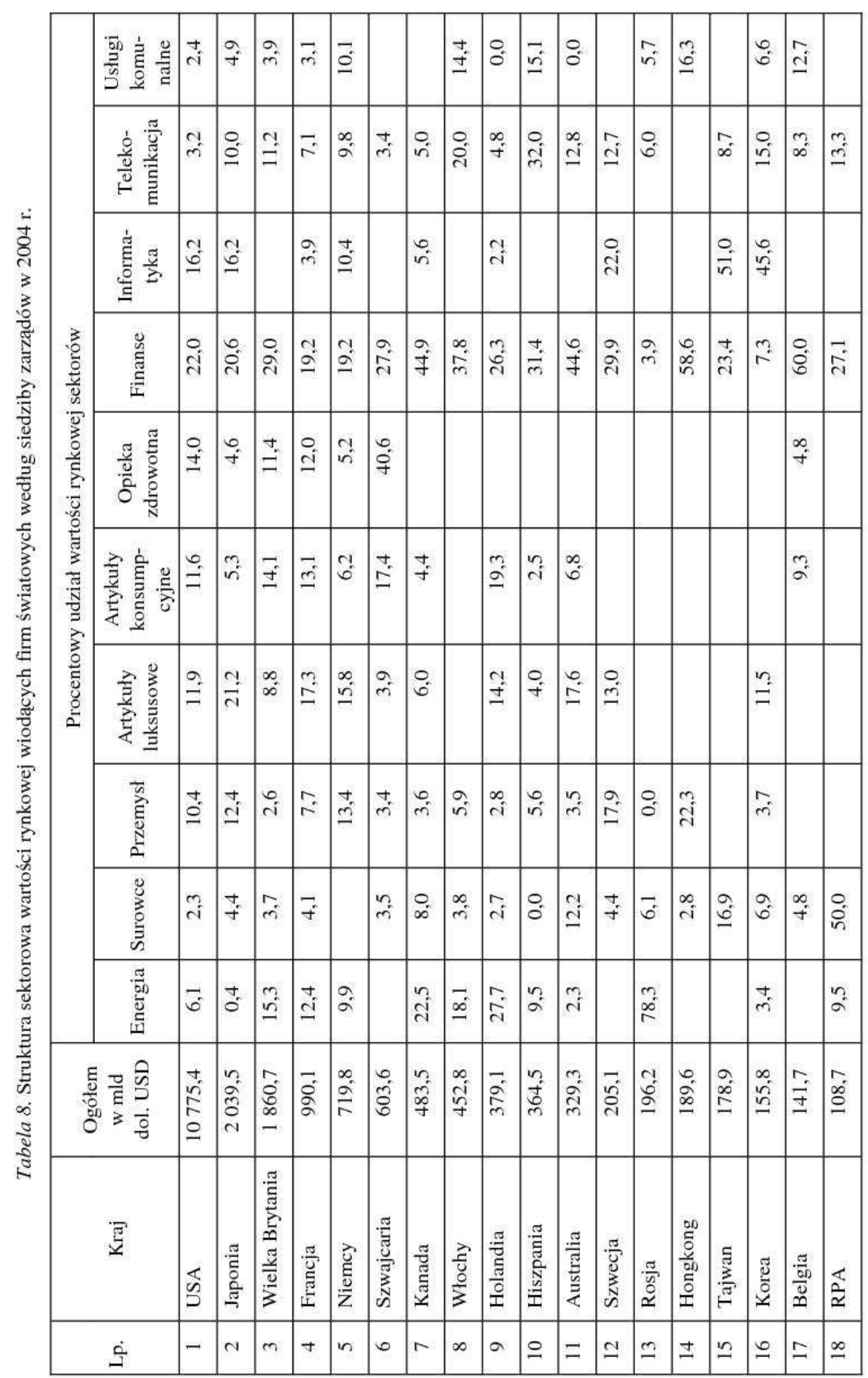




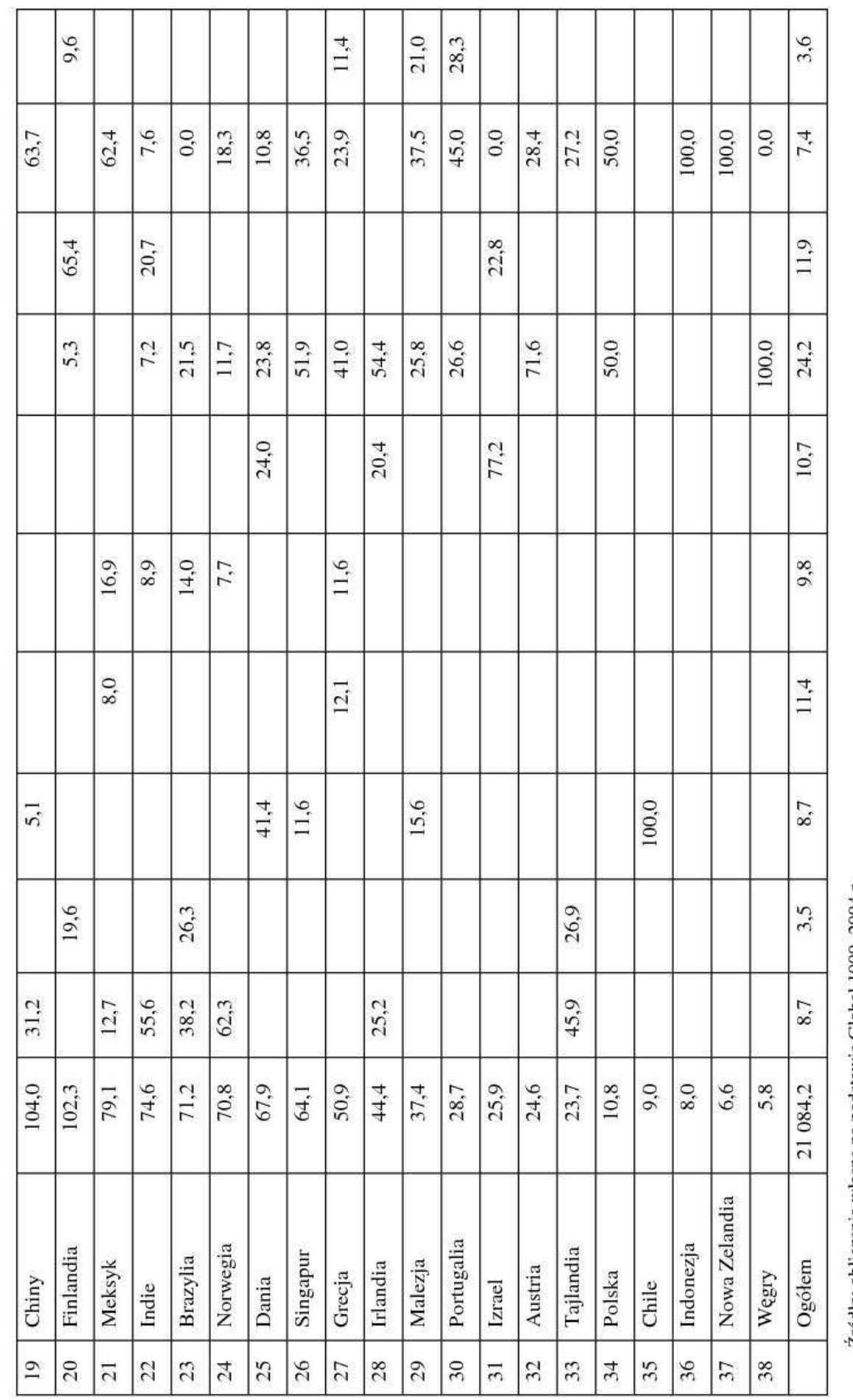


darstw domowych, które są podstawowym warunkiem aktywizacji społeczno-gospodarczej układów lokalnych i regionalnych; po trzecie nawiązać do współczesnych tendencji rozwoju i przyśpieszać proces wchodzenia naszego kraju w fazę społeczeństwa informacyjnego, poprzez upowszechnienie kształcenia informatycznego i związanych z tym badań naukowych. Pozwoli to na przygotowanie wysoko kwalifikowanych kadr, które będą czynnikami podnoszącymi atrakcyjność naszego kraju i poszczególnych regionów dla uruchomienie mechanizmu rozwoju opartego na nauce i technologii. Przyczyni się to do intensywniejszego rozwoju inwestycji krajowych oraz napływu związanych z nimi bezpośrednich inwestycji zagranicznych. Realizowanie tego kierunku działań umożliwiają m.in. dobre wyniki kształcenia, w tym kształcenia informatycznego na polskich uczelniach oraz zagraniczne sukcesy kształconych w Polsce kadr.

\section{LITERATURA}

Domański B., 2002, Zagraniczne inwestycje przemystowe a obszary metropolitalne $w$ Polsce, [w:] Problemy transformacji struktur przemystowych (red. Z. Zioło), Prace Komisji Geografii Przemysłu nr 4, Warszawa-Kraków, s. 9-17

Huculak M., 2004, Przekształcenia własnościowe w przemyśle piwowarskim Polski po 1990 r., [w:] Przemiany struktur przemystowych (red. Z. Zioło, Z. Makieła), Prace Komisji Geografii Przemysłu PTG nr 7, Warszawa-Kraków, s. 71-85

Gierańczyk W., Stańczyk A., 2003, Korporacje międzynarodowe w przestrzeni globalnej, [w:] Ksztattowanie się struktur przemystowych (red. Z. Zioło, Z. Makieła), Prace Komisji Geografii Przemysłu nr 5, Warszawa-Kraków, s. 73-83

Namyślak B., 2004, Kapitat zagraniczny w specjalnych strefach ekonomicznych w Polsce, [w:] Przemiany struktur przemystowych (red. Z. Zioło, Z. Makieła), Prace Komisji Geografii Przemysłu PTG, Warszawa-Kraków, s. 25-30

Rachwał T., 2003, Globalne uwarunkowania restrukturyzacji przedsiębiorstw Polski PotudniowoWschodniej, [w:] Przemyst w procesie globalizacji (red. Z. Zioło Z. Makieła), Prace Komisji Geografii Przemysłu PTG nr 6, Warszawa-Kraków, s. 129-138

Sala S., 2003, Wybrane cechy dziatalności korporacji transnarodowych i ich implikacje dla Polski, [w:] Przemyst w procesie globalizacji (red. Z. Zioło Z. Makieła), Prace Komisji Geografii Przemysłu PTG nr 6, Warszawa-Kraków, s. 101-107

Stańczyk A., 2003, Społeczno-gospodarcze aspekty konkurencyjności Polski w warunkach globalizacji, [w:] Przemyst w procesie globalizacji (red. Z. Zioło Z. Makieła), Prace Komisji Geografii Przemysłu PTG nr 6, Warszawa-Kraków, s. 87-100

Stryjakiewicz T., 2001, Orientacja teoretyczno-metodologiczna $w$ geografii przemystu a transformacja gospodarki, [w:] Problemy przemian struktur przemystowych $w$ procesie wdrażania regut gospodarki rynkowej (red. Z. Zioło), Prace Komisji Geografii Przemysłu nr 3, WarszawaKraków, s. 13-25

Tkocz M., 2003, Przejawy procesu globalizacji w przemyśle województwa ślaskiego, [w:] Przemyst w procesie globalizacji (red. Z. Zioło Z. Makieła), Prace Komisji Geografii Przemysłu PTG nr 6, Warszawa-Kraków, s. 67-76

Wajda E. 2003, Proces ksztattowania się Motoroli jako firmy ponadnarodowej, [w:] Kształtowanie się struktur przemystowych (red. Z. Zioło, Z. Makieła), Prace Komisji Geografii Przemysłu PTG nr 6, Warszawa-Kraków, s. 85-114

Wajda E., Zalewska K., 2003, Struktura przestrzenno-organizacyjna korporacji General Motors, [w:] Przemyst w procesie globalizacji (red. Z. Zioło Z. Makieła), Prace Komisji Geografii Przemysłu PTG nr 6, Warszawa-Kraków, s. 119-127 
Wajda E., Zorićić-Wołek M., 2003, Proces kształtowania się korporacji IBM, [w:] Przemyst w procesie globalizacji (red. Z. Zioło Z. Makieła), Prace Komisji Geografii Przemysłu PTG nr 6, Warszawa-Kraków, s. 109-117

Wieloński A., 2003, Przemyst nowej gospodarki, [w:] Przemyst w procesie globalizacji, (red. Z. Zioło Z. Makieła), Prace Komisji Geografii Przemysłu PTG nr 6, Warszawa-Kraków, s. 21-25

Zioło Z., 2001, Struktura branżowa i koncentracja przestrzenna wiodacych światowych firm przemystowych, [w:] Problemy przemian struktur przemystowych $w$ procesie wdrażania regut gospodarki rynkowej (red. Z. Zioło), Prace Komisji Geografii Przemysłu, nr 3, Warszawa-Kraków, s. $29-41$

Zioło Z., 2003, Kształtowanie się przedsiębiorstw przemystowych w procesie globalizacji, [w:] Przemyst $w$ procesie globalizacji (red. Z. Zioło Z. Makieła), Prace Komisji Geografii Przemysłu PTG nr 6, Warszawa-Kraków, s. 9-19

Zioło Z., 2004, Kształtowanie sie firm informatycznych jako nowych elementów struktury przestrzennej przemystu, [w:] Przemiany struktur przemystowych (red. Z. Zioło, Z. Makieła), Prace Komisji Geografii Przemysłu PTG nr 7, Warszawa-Kraków, s. 97-106

Zioło Z., Piróg S., 2002, Lokalizacja zarzqdów i potencjat ekonomiczny wiodacych firm zachodnioeuropejskich, [w:] Problemy transformacji struktur przemystowych (red. Z. Zioło), Prace Komisji Geografii Przemysłu nr 4, Warszawa-Kraków, s. 25-36 